\author{
St ud i P hilos o p h i a \\ Wr a t i s l a vi e n s i a \\ vol. XIII, fasc. 4 (2018) \\ DOI: $10.19195 / 1895-8001.13 .4 .5$
}

\author{
JOANNA HAŃDEREK \\ ORCID: 0000-0001-7482-2718 \\ Uniwersytet Jagielloński
}

\title{
Dialektyka równości i nierówności
}

Wykluczenie, marginalizacja, obojętność — z jednej strony problemy te wydają się już szeroko omówione w naukach społecznych i humanistycznych, z drugiej strony, moim zdaniem, ciągle mamy za mało świadomości, czym tak naprawdę jest wykluczenie, co ono oznacza dla tych, którzy są wykluczani, jakie są mechanizmy ekskluzji. Od czasów narodzin postkolonialnej myśli, przez rozmaite dekonstrukcje postmodernistyczne czy poststrukturalistyczne, zostały stworzone narzędzia do analizy różnych form społecznej marginalizacji czy ekskluzji. Fakt jednak, iż ciągle zachodzące w społeczeństwie procesy wykluczania ożywiają z nową siłą stereotypy, rasizm i uprzedzenia, pokazuje, jak bardzo ważny jest namysł nad tymi zjawiskami.

Z tej perspektywy ukazanie się książki Michała Kozłowskiego Znaki równości. O społecznym konstruowaniu stosunków egalitarnych ${ }^{1}$ stanowi bardzo ważny krok w dyskusji o wykluczonych i wkluczeniach. Jest to krok w długiej dość drodze prowadzącej (przynajmniej mam taką nadzieję) do otwarcia na innych, zrozumienia obcości drugiego człowieka i zbudowania szacunku wobec niego. Jest to jednak droga trudna, kolejne książki i kolejne monografie będą uzupełniały tę ścieżkę. Przed nami pozycja otwierajacca debatę o wnikliwych analizach filozoficznych, z dużą znajomością zarówno problemu, jak i tradycji nauk społecznych — innymi słowy, książka pozwalająca na podjęcie dyskusji dla nas wszystkich bardzo ważnej, dotyczącej w gruncie rzeczy przyszłości. Ponieważ praca Kozłowskiego jest wyjątkowo bogata w treści i poruszane problemy, postaram się w omówieniu pokazać, co moim zdaniem jest szczególnie ciekawe i cenne w debacie na temat współczesności. Zacznijmy od samego początku lektury.

Kozłowski podejmuje bardzo istotny problem wykluczenia społecznego, różnych form przemocy społecznej i marginalizacji w społeczeństwie. Jak we wstępie zazna-

${ }^{1}$ M. Kozłowski, Znaki równości. O społecznym konstruowaniu stosunków egalitarnych, Warszawa 2016.

Studia Philosophica Wratislaviensia 13, 2018 z. 4, (C) for this edition by CNS 
cza, jest to tematyka w ostatnich latach popularna (nawet modna), a wykluczenie i marginalizacja badane są na różnych polach nauk społecznych i humanistycznych (socjologii, filozofii czy psychologii). Podejmowanie zatem tak mocno dyskutowanej tematyki zawsze wiąże się z obciążeniem badawczym poruszania się po tematach już opisanych, przebadanych czy kontrowersyjnych i ciągle wymagających debaty. Kozłowski w swojej książce przyjmuje filozoficzną metodę badawczą, analizując problemy od strony filozofii społecznej i filozofii kultury, co pozwala rzucić nowe światło interpretacyjne czasami na stare problemy społeczne, co czyni jego monografię jednym z ważniejszych głosów we współczesnej dyskusji nad wykluczeniem. Co jednak najważniejsze, pisze o problemach społecznych z niezwykła wrażliwością badawczą, prezentując wyważone stanowisko interpretacyjne, otwierające przed czytelnikiem własne interpretacje i pytania. Jak słusznie zauważył w recenzji wydawniczej Marcin Poręba: „Kozłowski prowadzi swe wywody z wielką kulturą, unikając wszelkiej tendencyjności i doktrynerstwa”. Ta właśnie postawa badawcza powoduje, że książka Znaki równości pozwala na namysł nad społecznymi uwarunkowaniami i relacjami oraz oferuje pełen przegląd problematyki bez zbędnego wartościowania czy ideologizacji problemu.

$\mathrm{W}$ wstępie, stanowiaccym klarowne wprowadzenie do badanej tematyki, autor wykłada swoją tezę badawczą mówiącą o polityczności relacji społecznych; będzie ona badana w dalszych rozdziałach za pomoca analizy filozofii Marksa, Foucaulta, Bourdieu, Braudela.

Równość traktujemy jako konstrukt, a więc także stosunek społeczny. [...] Przedmiotem mojego zainteresowania są wszystkie te momenty, w których relacje społeczne zakładają lepszość-gorszość, nadrzędność-podrzędność, władzę-podporządkowanie, bogactwo-niedostatek są kwestionowane w całości lub części².

W ten sposób Kozłowski przygotowuje czytelnika na analizy ukrytych nierówności i zależności, tak samo jak na badanie kształtowania się relacji społecznych w wymiarze zależności oraz prób społecznego konstruowania równości i egalitaryzmu. Co moim zdaniem szczególnie interesujące, w dalszych rozważaniach Kozłowski będzie pokazywał, jak trudne jest zniesienie nierówności społecznych i jak często - paradoksalnie — walka z nierównością społeczną konstruuje nowe jej formy, co widać zarówno w teorii, jak i praktyce politycznej. Jest to swoisty paradoks, o którym rzadko się mówi, a który ma swoje uzasadnienie w egzystencjalnym aspekcie problemu: kiedy wykluczany zaczyna sam wykluczać zarówno samego siebie, jak i innych. Nierówność, można powiedzieć, rodzi nierówności, a polityka postkolonialna może być naznaczona wtórnym kolonizowaniem, o czym przekonaliśmy się, obserwując niejeden proces odzyskiwania niepodległości.

Rozdział pierwszy, Równość grecko-rzymska, umieszcza w kontekście historycznym i — jak podkreśla Kozłowski — ideowym kwestie nierówności społecznych. Wpisanie historycznej perspektywy w myślenie o wykluczeniu i marginalizacji ma swoją istotną funkcję: pozwala pokazać, jak stary i rozległy jest to problem, jak wiele zostało przepracowane i równocześnie, jak wiele form deprecjacji zostało ukrytych pod pozorem różnych zmian zachodzących w historii. Zasadniczą tezac

\footnotetext{
2 Ibidem, s. 23.
} 
tego rozdziału jest spostrzeżenie: „Równość (lub nierówność) da się myśleć jako zawartą w każdym stosunku społecznym"3. W rozdziale tym bardzo ważne staje się ukazanie, jak kształtowanie się nierówności społecznych wiąże się ze strategiami wartościowania w kategoriach moralności czy możliwości.

Znaki równości robią wrażenie swą badawczą konsekwencją, do której należy między innymi konsekwencja w śledzeniu pewnych kulturowych wzorców kształtujących nierówność w obrębie formowania systemów równościowych. Jak pokazuje Kozłowski,

ustanowienie wspólnoty równych splata się nierozerwalnie z tym silniejszym obniżeniem statusu i wykluczeniem tych, którzy pozostają poza tą wspólnotą — w tym wypadku (a jest to zestaw historycznie niemal uniwersalny) kobiet, niewolników i cudzoziemców ${ }^{4}$.

Dalsze rozdziały, Wykluczający uniwersalizm oraz Równość przez ustanowienie, kontynuują tę myśl, zmagając się równocześnie z tą wewnętrzną sprzecznością ustanowienia, konstruowania czy walki o równość. Wskazanie na mechanizm ekskluzji zawarty w polityce równości jest tutaj kluczowe, a pokazując, w jaki sposób, budując równość społeczną, wydziela się tych, którzy do społeczeństwa nie należą, a zatem nie są równi i nimi stać się nie mogą, pozwala na rozwinięcie dalszych analiz. Co ważne, Kozłowski ukazuje ten mechanizm wykluczenia jako swoisty model, powtarzający się w wielu politycznych strategiach, często też nieuświadamiany, a przez to czyniący utopijnymi idee i koncepcje wielu filozofów polityki czy samych polityków.

Za punkt wyjścia omawianej książki została obrana koncepcja Michela Foucaulta; pojawiająca się już na początku analiza jest konsekwentnie rozwijana w kolejnych rozdziałach. Kozłowski wykorzystuje bogatą spuściznę francuskiego filozofa, sięgając do takich pozycji, jak: Dits et ecrits, Le courage de la vérité: le gouvernement de soi et des autres, Historia seksualności, Historia szaleństwa w dobie klasycyzmu, Nadzorować i karać: narodziny więzienia czy Narodziny biopolityki. To szerokie ujęcie, od wykładów do monografii, pozwala wydobyć Foucaultowską krytykę społecznych mechanizmów dominacji oraz prześledzić, w jaki sposób nierówności społeczne stały się naturalnym elementem gry społecznej.

Rozdział drugi, Rzadzenie równościa, zaczyna się od analizy samego tytułowego zwrotu. Jak przyznaje autor, kryje się w nim sprzeczność, co z wiadomych względów (równość przecież konstruowana jest przeciwko rządzeniu) wydaje się oczywiste. Jednak w świetle wcześniejszych rozważań takie spostrzeżenie oczywiste już nie jest. Opierając się właśnie na Foucaulcie, można dostrzec, że równość społeczna jest jedną z technik zarządzania rzeczywistością. Kozłowski wprowadza rozróżnienie na rządzenie równością, które jest społecznym działaniem polegającym na tym, że ludzie mają poczucie równości lub dążą do egalitaryzmu, co prowadzi do semantycznego zbliżenia równości z różnorodnością (równość w różnorodności, różnorodność jako wyzwanie dla równości). W drugim znaczeniu mamy do czynienia z narzędziem władzy — w tym kontekście równość jest w służbie władzy i jej technik, stając się metodą oddziaływania na społeczeństwo. Wskazując na te dwa

\footnotetext{
3 Ibidem, s. 29.

4 Ibidem, s. 33.
} 
znaczenia „rządzenia równością”, autor pokazuje, w jaki sposób równość może być albo świadomością uczestników gier społecznych (co nie przekreśla tego, że jest ona konstruowana przez polityczne i historyczne uwarunkowania), albo technika zarządzania (a w niektórych wypadkach może być wręcz socjotechniką manipulowania ludźmi). W ten sposób do wcześniejszych sprzeczności w obrębie egalitarnych idei dołożona zostaje kwestia równości jako narzędzia politycznego. Moim zdaniem w analizach tych Kozłowski tworzy interesującą dialektykę równości i nierówności, zgodnie z którą pomiędzy tymi dwoma zjawiskami wyłaniają się społeczne możliwości i problemy. W dialektyce tej wyraźna jest również dość smutna konkluzja: nierówności nie da się wyeliminować (całkowicie) z życia społecznego, tak samo jak nie da się usunąć traktowania równości społecznej jako narzędzia do wielu narracji wolnościowych i politycznych. Wymieniając świadomość społeczną, polityczną technikę, strategie stosowane w ekonomii i wojsku, autor pokazuje, jak poczucie równości, z jednej strony, może stać się świadomością człowieka, jego praw i obowiązków, a z drugiej strony, jak wytwarzane są całe mechanizmy społecznego zarządzania i działania, kształtujące poczucie możliwości równości, a przez to motywujące do wydajności.

Chociaż w swych analizach autor zajmuje się stanowiskiem Foucaulta, przywołuje Richarda Sennetta czy Karola Marksa, brakuje, moim zdaniem, odwołania do szkoły frankfurckiej. I tutaj podejmę polemikę z Kozłowskim, przyjmując zachętę debaty płynącą z jego tekstu. Moim zdaniem szkoły frankfurckiej nie można pomijać, formułowała ona bowiem krytykę relacji społecznych oraz pozwalała na kształtowanie się kontrkultury znoszącej wiele nierówności. W Człowieku jednowymiarowym Herberta Marcusego, czy w pracach Theodore'a Adorno i Maxa Horkheimera, została rozwinięta koncepcja kultury jako mechanizmów podporządkowujących człowieka samej strukturze kulturowej i polityce. W ten sposób frankfurtczycy wskazują na siłę warunkowania kulturowego, opartą często na ukrytych modelach postępowania. Wolność i równość mogą w tym aspekcie stać się takim samym narzędziem jak w technikach „rządzenia równością” ujmowanych przez Kozłowskiego. Szersze odniesienie do szkoły frankfurckiej pozwoliłoby również w sposób naturalny uzupełnić analizy filozofii Marksa, która to właśnie przez frankfurtczyków wchodziła do wielu debat europejskich. Pominięcie Człowieka jednowymiarowego to pominięcie również opus magnum twórców idei kontrkulturowych, z istoty stawiających na inkluzję i przemieszczenie peryferii w sferę centrum.

W analizie ,zarządzania równością" w perspektywie kapitalizmu nie mogło zabraknąć analiz filozofii Marksa, co Kozłowski dokonuje w sposób elokwentny i interesujaccy. Filozofia Marksa, analizowana na podstawie: Manifestu komunistycznego, Kapitału, Przyczynku do krytyki heglowskiej filozofii prawa, Kwestii żydowskiej, 18 brumaire'a Ludwika Bonaparte, staje się podstawą do pokazania zawiłości społecznych i rozwarstwienia, które często wykracza poza proste podziały.

Analiza kapitalizmu i stosunków społecznych wobec ekonomii, w odniesieniu do filozofii Marksa, prowadzi Kozłowskiego do ważnego spostrzeżenia. Pisząc o przewartościowaniu stosunków społecznych oraz o zerwaniu z feudalnymi relacjami, autor odnotowuje: 
Burżuazja postępuje inaczej: zarówno, jeśli chodzi o władzę ekonomiczną w kapitalizmie, jak i władzę polityczną w liberalnej demokracji, wprowadzone zostają zasady konkurencji jako konstytutywne dla systemu produkcji oraz systemu reprodukcji tak władzy politycznej, jak kapitału ${ }^{5}$.

Konkurencyjność jest tutaj problemem podstawowym, zmieniajacym relacje społeczne i wprowadzającym, jak słusznie pokazuje Kozłowski, nowy rodzaj mechanizmów równości, które mają ukryte formy ekskluzji.

Konkurencyjność stanowi bowiem rodzaj możliwości, jakie zostają przypisane w punkcie wyjścia wszystkim uczestnikom zdarzenia społecznego, niezależnie od tego, czy mówimy o ekonomii i miejscu w pracy, czy edukacji lub polityce. Ważne w konkurencyjności nie jest bowiem pochodzenie czy urodzenie, lecz sama zdolność i możliwości, jakie będzie rozwijał człowiek. Przyglądając się jednak konkurencyjności dogłębniej, można zauważyć, że działa ona zarówno egalitarystycznie, jak i elitarnie. Możliwości ludzi nigdy bowiem nie są takie same (zarówno na początku współpracy, jak i podczas jej rozwoju), nigdy też konkurujący z sobą nie działają w tym samym paradygmacie, z tą samą pracowitością czy zdolnością. Same różnice między ludźmi mają już charakter wartościujący. Dzięki filozofii Marksa autor Znaków równości może pokazać, w jaki sposób zmieniają się same klasy, w jaki sposób dochodzi do przewartościowania zasad społecznego funkcjonowania przy równoczesnym konstytuowaniu nowych podziałów i nowych nierówności. Sama konkurencyjność wymaga przecież umiejętności konkurowania i możliwości podjęcia działań stwarzających warunki czy szanse na bycie konkurencyjnym względem innych.

W swoich rozważaniach Kozłowski ujmuje problem „zarządzania równością”, a przez to strategii inkluzji i ekskluzji w świetle historii. Wymieniając „trzy wielkie rewolucje, które wstrząsnęły światem pod koniec XVIII stulecia: amerykańsk[ą], francusk[ą] i haitańsk[a] ]", autor wskazuje na ważne czynniki kulturowe, dziejowe i etniczne, kształtujacce postawy i idee ludzi. Zwłaszcza rewolucja haitańska, pokazująca relacje kolonialne i dążenia wolnościowe, stanowi świadectwo, że nierówność społeczna nierzadko oznacza coś o wiele więcej niż nierówność w dostępie do dóbr ekonomicznych czy edukacji. W rewolucji haitańskiej przede wszystkim zostaje uświadomiona nierówność pomiędzy tymi, którzy mogą poszczycić się prawomocnie swoim człowieczeństwem, a tymi, którym odbiera się człowieczeństwo. Jest to też ukazanie „pustki” idei „,wolności, równości i braterstwa”, gdyż ten fałszywy egalitaryzm odnosi się do członków białego społeczeństwa i to w praktyce wyłącznie do mężczyzn (prawa wyborcze kobiet). Spojrzenie z tej historycznej perspektywy pozwala zatem rozprawić się z mitem uniwersalnych praw człowieka, a w gruncie rzeczy z samą koncepcją człowieczeństwa.

W tym aspekcie rozważań ponownie należy zwrócić uwagę to, że w przedstawionych analizach zabrakło obecności samych postkolonialnych myślicieli. Kozłowski, ze szkodą dla prezentowanego problemu, pomija między innymi Roberta Younga z jego analizą fałszywego uniwersalizmu, jaką zawarł w książce White Mythologies. Writing History and the West, w pracy tej Young pokazuje, jak uniwersalizacja

\footnotetext{
5 Ibidem, s. 68.

${ }^{6}$ Ibidem, s. 75 .
} 
i odwołanie się do metafizycznych kategorii europejskiego myślenia staje się narzędziem budowania przemocy wobec wszystkich tych, których wyklucza się ze wspólnoty ludzkiej, czyniąc ich dzikusami, barbarzyńcami czy innymi rasami. Ponadto brak odniesienia do Rossi Braidotti powoduje, że możliwość krytycznej analizy nie zostaje pogłębiona przez odwołania do modelu zuniwersalizowanego/doskonałego człowieka, metaforycznie ujętego w modelu witruwiańskim. Zarówno Braidotti, jak i Young bardzo klarownie pokazują, że wszelka uniwersalizacja staje się kategorią unifikacji człowieka, sprowadzając go do kilku cech ugruntowanych w tradycji europejskiej filozofii, przechodząc w praktykę życia codziennego, kończącą się wykluczeniem. Często też wykluczenie to oznaczało ekskluzję najsłabszych obywateli: chorych, kobiet, migrantów, ludzi innych wyznań i innych etniczności. W rozprawie Kozłowskiego problem ten jest silnie zarysowany, dlatego uzupełnienie o te analizy pozwoliłoby na dopełnienie dyskusji, a może nawet na otwarcie nowego problemu współczesnej postkolonialnej problematyki.

Problematyczne wydaje się też porównanie skolonizowanych społeczeństw do klasy robotniczej w Europie. Wprawdzie Kozłowski podążą za starą interpretacją kolonialnej myśli, widocznej już w samych rozważaniach Frantza Fanona, który zwłaszcza w Les Demnés de la terre czyni takie porównanie, ugruntowane później przez Jean-Paula Sartre'a, czy we wczesnej myśli postkolonialnej, jednakże jest to interpretacja ograniczająca samą ideę oraz przepracowana i skrytykowana przez późniejszych badaczy postkolonialnych. Postkolonializm lat siedemdziesiątych przeobraża się pod wpływem Edwarda Saida, a w latach dziewięćdziesiątych i na początku XXI wieku pojawia się myślenie postkolonialne, polemizujące z takim ujęciem. Przede wszystkim dla współczesnych postkolonialnych myślicieli porównanie walk skolonializowanych społeczeństw do ruchów robotniczych Europy zakłada uniwersalizację i europocentryczne spojrzenie na problem, czego mimo zdaniem współcześnie nie wolno nam robić. Ponadto wielu postkolonialnych działaczy bardzo często odwoływało się do idei komunizmu jako alternatywy wobec kolonialnego systemu, równocześnie przetwarzając i przekraczając doktryny ruchu robotniczego.

Rozdział trzeci, Wykluczający uniwersalizm, stanowi uzupełnienie rozważań poprzedniego rozdziału z perspektywy idei uniwersalizmu, analizowanej na przestrzeni różnych koncepcji i różnych społecznych zastosowań.

Jeżeli wszyscy mają na równi uczestniczyć we władzy, kwestia tego, kim dokładnie są owi „wszyscy", staje się szczególnie paląca i niebezpieczna. [...] Nie inaczej ma się sprawa z uniwersalizmem jeśli prawo, rozum i siła mają przysługiwać wszystkim, trzeba najpierw zapewnić, żeby nie wpadły w niepowołane ręce ${ }^{7}$.

Równość szans, jak pokazuje autor Znaków równości, ma pozorny charakter od samego pojawienia się wolnego rynku i opartych na nim stosunków społecznych, ponieważ wzrost gospodarczy imperiów XIX stulecia opierał się na kolonialnym wyzysku. We wzroście założone jest zubożenie, we władzy na kapitałem założone jest zniewolenie tych ludzi, którzy nie mogą uczestniczyć w postępie i możliwościach rozwoju ekonomicznego. Niewolnictwo jest tutaj skrajnym przykładem me-

7 Ibidem, s. 105. 
chanizmów rządzących wykluczeniem wszystkich tych ludzi, których pozbawiono podmiotowości.

Michał Kozłowski wraca do filozofii Foucaulta, dekonstruującego techniki władzy jako ukrytej przemocy, często przyjmującej możliwość zafałszowania rzeczywistości i wzajemnych stosunków pomiędzy ludźmi. Widać to zwłaszcza na gruncie ekonomiczno-politycznym; jak pisze Kozłowski:

fałszywy uniwersalizm obywatelstwa ukrywa nie tyle formalną bezwolność i wynikającą z niej pracę najemną pod osłoną umów i wolnego rynku pracy i towarów, ile realne podporządkowanie jednostek, brak rzeczywistej kontroli nad własnym życie ${ }^{8}$.

W ten sposób w interpretacji Foucaulta powraca myśl Marksa o alienacji i wyzysku alienowanych, przy czym w świecie opisanym przez francuskiego poststrukturalistę wyzysk ten został ubrany w formy umowy pozorującej wolność jednostki i jej nieograniczone możliwości. Jest to jeden z tych momentów książki Kozłowskiego, w którym widać kunszt interpretatorski, przechodzenie autora z łatwością od interpretacji klasycznych filozofów współczesności po własne spostrzeżenia i konkluzje, co czyni lekturę niezwykle interesującą. Równocześnie ciągłe przesunięcia interpretacyjne pomiędzy myślą Marksa a Foucaulta, zabarwione filozofia francuską, dają szerokie pole postrzegania problemu, umożliwiające naświetlenie wszystkich skrywanych i niejasnych nierówności społecznych, nawet w pozornym dyskursie i prawie równości i równouprawnień. Można by wręcz rzec, że pod piórem Kozłowskiego przechodzi w Nadzorować i karać czy Biopolityke, wskazując na ciągłą nierówność wpisaną w system kultury Zachodu.

W rozdziale tym autor wraca również do problemów postkolonialnych, tym razem ukazując bolesną aktualność słów Edwarda Saida o podziale na barbarzyński Wschód i cywilizowany Zachód (przypominam moją powyższą polemiczną uwagę, nowy postkolonializm po prostu jest potrzebny do rozwinięcia myśli Kozłowskiego). Ukryty mechanizm warunkowania i deprecjonowania uczestników gry społecznej obecny jest również w kolonialnych i później neokolonialnych uwarunkowaniach relacji pomiędzy kulturami. Jak celnie zauważa Kozłowski, człowiek Zachodu dostaje uniwersalne i zarazem stałe prawo do posiadania nie tylko własnej tożsamości, lecz także mądrości - to bowiem, co robi, pozostaje słuszne i zgodne z prawem - a więc tym samym legitymizujące najpierw jego wartość jako kolonizatora, a obecnie jako ukrytego imperatora. Ta nieusuwalna w uniwersalizmie wartość jedynych zachodnich wartości, modeli i postaw ma charakter sankcjonujący, przenosząc się na kolejne relacje w stosunku do kolonii i byłych kolonii.

Chociaż Kozłowski nie wspomina o subaltern studies (a w tym miejscu wypadałoby wspomnieć choćby Gayatri Ch. Spivak, co jest moim zdaniem znacznym niedopatrzeniem ze strony autora), wyraźna jest w jego analizach struktura podwójnego uprzedmiotowienia kolonialnego-neokolonialnego, innej kultury oraz wewnętrznych struktur kulturowych, które deprecjonując poszczególne kasty lub płeć, powodują, że uprzedmiotowienie staje się podwójne. Już na płaszczyźnie symbolicznej kobieta oznacza tą, która jest podporządkowana, jak i staje się sym-

\footnotetext{
8 Ibidem, s. 113.
} 
bolem skolonizowanych ludów czy regionów (Afryka jest kobietą). Spivak zwraca uwagę na to podwójne uprzedmiotowienie i w życiu poprzez wzorce kulturowe, i symboliczne przez ujmowanie kobiecości i nadanie jej statusu podrzędności. Niewątpliwie odwołanie się do Simone de Beauvoir i jej klasycznej z perspektywy drugiej fali feminizmu „drugiej płci” pozwala Kozłowskiemu ukazać ten walor uprzedmiotowienia często niedostrzegany przez społeczeństwo i traktowany jako coś przynależnego samej kobiecości.

Czwarty rozdział, Sprawczość zdominowanych, stawia badane przez autora problemy w zupełnie innym świetle: z perspektywy pytania, czy sami uprzedmiotowieni, wykluczeni i marginalizowani ludzie mogą stać się dla siebie wyzwoleniem? Na ile mają świadomość konieczności walki o swoje prawa? Na ile ich walka jest świadoma, a na ile jest jedynie manipulacją tych, którzy niejako za nich podejmuja decyzję.

W rozdziale tym Kozłowski zachowuje swoją metodę wyszukiwania w tym, co zdaje się oczywiste i proste, niepokojących sprzeczności, dlatego można dostrzec konstruowanie przez niego teorii aporii oporu. Przywołując Luca Boltanskiego, nasz autor pokazuje, jak — z jednej strony — walka z instytucjami porządku społecznego denuncjuje pewne formy działania tychże instytucji, przy równoczesnym potwierdzeniu samego ich istnienia. W ten sposób walka z instytucją staje się jej wzmocnieniem poprzez afirmowanie jej samego istnienia. Z drugiej strony, pojawia się realna możliwość działania wykluczonych, pytanie o kompetencje i możliwości działania osób marginalizowanych wcześniej w społeczeństwie, a więc często bez odpowiedniego dostępu zarówno do edukacji, jak i kapitału. Jak słusznie zauważa Kozłowski, aporia ta ujawnia sprzeczności rozwiązywania problemu, gdyż często zostaje on rozstrzygnięty za potrzebujących, tworząc kolejne poziomy nierówności. Trzecim problemem, jaki ujawnia autor, jest kwestia możliwości budowania nowego ładu, rzeczywistości istotnie egalitarnej. Biorąc pod uwagę fakt zróżnicowania, jakie zachodzi pomiędzy samymi ludźmi, jest to zadanie trudne; dodatkowo rewolucjoniści mogą nie mieć kompetencji społecznych do zmian strukturalnych społeczeństwa.

Ten właśnie aspekt prób zmiany społeczeństwa, wprowadzenia egalitaryzmu, mechanizmów prowadzących do inkluzji może nie tylko być obarczony samą dwuznacznością strukturalną - społecznych mechanizmów wartościowania, kategoryzowania i marginalizowania — ale również okazać się trudny ze względu na samą mentalność, wiedzę i możliwości działania osób walczących na rzecz poprawy kondycji ludzkiej. Uniwersalizm przedstawiany wcześniej przez Kozłowskiego z tej perspektywy zostaje rozbity na wewnętrzne zróżnicowanie postaw, świadomości oraz umiejętności, jakie posiadają organizujący się ludzie.

Moim zdaniem szczególnie ważny w wywodach omawianej książki jest zawarty w niej sposób problematyzowania; wskazując na aporie oporu, równocześnie zawiesza się wartościowanie ludzi czy deprecjonowanie ich działań, omawiając tylko konsekwencje, zarówno w wymiarze socjologicznym, jak i filozofii społecznej. Jest to tym samym bardzo cenna analiza, gdyż nie stawia czytelnika przed wyborem właściwych działań, a zmusza do myślenia, dając refleksję nad złożonością postępowania i ukrytych w nim motywów, jak i samych możliwości realizacyjnych. Co 
równie ważne, Kozłowski pokazuje, że spojrzenie teleologiczne ma swoje głębokie znaczenie; bez urealniania celu i kalkulacji wszystkich możliwych scenariuszy możemy stanąć przed wykładnią Alberta Camusa, zgodnie z którą bunt w swej szlachetnej postaci działania w imię drugiego człowieka przeradza się w rewolucję z całym jej okrucieństwem.

Ostatni rozdział, Równość przez ustanowienie, może być czytany jako studium osobowości i przypadku. Lenin, Ambedkar i Krystyna K. — jak tłumaczy Kozłowski:

Trzy przedstawione tu figury woluntarystycznego i politycznego ustanowienia równości istotnie się różnią — łączy je przede wszystkim to, że zostały w jakiś sposób zniweczone, odwrócone, w najlepszym razie radykalnie ograniczone i zakonserwowane ${ }^{9}$.

Od strony politycznej i ideowej Lenin staje się przywódcą tylko po to, by stać się figurą rewolucji, oferującej zamiast egalitaryzmu inną formę władzy i elitarności. Ambedkar od strony społecznej staje się rewolucją przewartościowania kastowego, by stać się symbolem nietykalnych i równocześnie przejść do innej klasy społecznego funkcjonowania w świecie. Wreszcie, anonimowa Krystyna, która nie może korzystać z rozwoju praw kobiet, tylko dlatego że zmienia się sama władza i przez to ideologia. Z tej trójki najmniej świadoma uczestniczka społecznych zmian równocześnie je wyraża, odchodząc i szukając nowej pracy na przekór zmienności. W tym ostatnim rozdziale, jeszcze przed zakończeniem, autor wyraża chyba najdobitniej dwuznaczność zarówno uniwersalizmu, rządzenia równością, jak i samej sprawczości. W wypadku konkretnego człowieka, niezależnie od tego, czy trafi on później do mauzoleum, czy spotka go inny los, mamy do czynienia z konfrontacją kulturowych paradygmatów, ukrytych założeń, intencji, a także marzeń oraz wizji rzeczywistości.

Książka Znaki równości Kozłowskiego stanowi jedną z ciekawszych autorskich analiz wykluczenia, równocześnie badając i interpretując klasycznych myślicieli XX stulecia. Kozłowski zręcznie łączy interpretację filozofów z przełożeniem ich języka oraz analiz na współczesny świat, pokazując wieloaspektowość polityki i społeczeństwa. W polskiej literaturze takich tekstów potrzeba więcej, a książka Kozłowskiego może stać się przyczynkiem do bardzo ciekawej dyskusji, zwłaszcza że napisana jest językiem merytorycznym i równocześnie z przyjemną dla czytelnika swadą. Mam nadzieję, że droga do debaty została otwarta, czego życzę każdemu czytelnikowi tej fascynujaccej lektury.

\footnotetext{
${ }^{9}$ Ibidem, s. 219.
} 